\title{
KONSEP PENDIDIKAN ISLAM DALAM HIZBUT TAHRIR
}

\author{
Haniah Mase \\ MIN 4 Pondok Pinang Jakarta \\ haniahmase@gmail.com
}

\begin{abstract}
Hizbuttahrir is synonymous with the Islamic caliphate or the establishment of an Islamic state. Since the beginning of this organization, it has actually proclaimed itself as an organization that was founded because of the failure of a number of previous organizations that wanted to establish an Islamic state such as the Muslim Brotherhood (IM). This paper will explain the other side of Hizbuttahrir related to the concept of education developed by Taqyuddin an-Nahbany, as the founder of Hizbuttahrir.
\end{abstract}

Kata kunci: Hizbut Tahrir, Pendidikan, Konsep, Rahim.

\section{A. Pendahuluan}

Hizbuttahrir identik dengan khilafah Islamiyah atau pendirian negara Islam. Sejak awal organisasi ini, sejatinya telah memproklamirkan dirinya sebagai organisasi yang berdiri karena kegagalan sejumlah organisasi sebelumnya yang ingin mendirikan negara Islam seperti Ikwanul Muslimin (IM). Makalah ini akan menjelaskan sisi lain dari Hizbuttahrir terkait dengan konsep pendidikan yang dibangun oleh Taqyuddin an-Nahbany, sebagai pendiri Hizbuttahrir.

\section{B. Riwayat Hidup dan Latar Belakang Sosial Taqyuddin an-Nabhânî.}

An-Nabhânî, yang nama lengkapnya, Syeikh Muhammad Taqiyuddin Ibn Ibrahim Musthafa ibn Ismâil ibu Yûsûf an-Nabhânî, dinisbahkan kepada kabilah Bani Nabhan, suatu suku atau kabilah bangsa Arab yang hidup di padang sahara, Palestina. Mereka bermukim di daerah Ijzim yang termasuk wilayah Haifa di Palestina Utara. Syeikh an-Nabhânî lahir pada tahun 1909 di sebuah daerah bernama Ijzim. Beliau mendapat didikan ilmu dan agama di rumah, dari ayah beliau sendiri, seorang syeikh yang dikenal sebagai faqih fiddin (ahli agama). Ayah beliau seorang pengajar atau guru ilmu-ilmu Syariah di Kementerian Pendidikan Palestina. Ibu Beliau juga menguasai beberapa cabang ilmu syariah yang diperolehnya dari ayahnya, Syeikh Yusuf ibn Ismail ibn Yusuf an-Nabhânî .

Beliau ini adalah seorang qadli (hakim), penyair, sastrawan, dan salah seorang ulama terkemuka dalam Daulah Utsmaniyah. Pertumbuhan syeikh Taqiyuddin dalam suasana keagamaan yang kental seperti itu, ternyata mempunyai pengaruh yang besar dalam pembentukan kepribadian dan pandangan hidup beliau. Beliau telah hafal Alquran seluruhnya dalam usia yang amat muda, yaitu di bawah usia 13 tahun. ${ }^{1}$

Beliau dibesarkan dalam sebauah keluarga terhormat, pejabat dan ulama, yang juga dikenal sebagai keluarga yang taat beragama. Kecerdasan otaknya sudah terlihat setelah

${ }^{1}$ Wamy, Gerakan keagamaan dan Pemikiran, Akar Idiologis dan Penyebarannya (Jakarta: al-Ishlahy Press, 1995), 88 . 
berhasil menghafal seluruh isi Alquran menjelang usia 13 tahun, sehingga kakeknya Syeikh Yusuf an-Nabhânî memberikan perhatian kepadanya. Kakeknya, memiliki hubungan erat dengan para penguasa khilafah, tepatnya para pejabat pemerintahan Khilafah Utsmaniyah, dari sini tampaknya ia mendapat pendidikan politik yang kemudian diturunkan kepada cucunya an-Nabhânî. Syeikh Taqiyuddin menerima pendidikan dasar-dasar ilmu Syariah dari ayah dan kakek beliau, yang telah mengajarkan hafalan Alqur'an, sehingga beliau hafal Alquran seluruhnya sebelum baligh. Di samping itu, beliau juga mendapatkan pendidikan di sekolah negeri ketika beliau sekolah di Sekolah Dasar di daerah Ijzim. Kemudian beliau pindah ke sebuah sekolah di Akka untuk melanjutkan pendidikan ke sekolah menengah. Sebelum beliau menamatkan sekolahnya di Akka, beliau bertolak ke Kairo pada tahun 1928 untuk meneruskan pendidikannya di Al-Azhar, guna mewujudkan dorongan kakeknya, Syeikh Yusuf an-Nabhânî. Sementara ia menjalani studi di Universitas Darul Ulum (Sekarang bernama Universitas Kairo), juga beliau berhasil merampungkan studinya di AlAzhar pada tahun 1932. ${ }^{2}$

Setelah kembali ke Palestina beliau mengawali aktivitasnya di Kementerian Pendidikan Palestina sebagai guru Sekolah Menengah Atas Negeri dan guru madrasah Islamiyah di Haifa, Palestina. Selama delapan tahun menekuni aktivitas pendidikan sebagai guru hingga kemudian beliau mengajukan alih pekerjaan di Mahkamah Syariah sebagai kepala sekretaris Mahkamah Syariah di Haifa. Prestasinya dalam menjalani karirnya sebagai kepala Sekretaris Mahkamah akhirnya beliau diangkat sebagai Musyawir (asisten qadli) pada tahun 1940. Akhirnya beliau sampai pada puncak profesinya di Mahkamah ketika ditunjuk sebagai Qadli (Hakim) di Mahkamah Ramallah pada tahun 1945. Demikian seterusnya hingga kembali dipercayakan untuk menjadi Hakim di daerah lain, tepatnya di Quds, dengan jabatan yang sama sebagai Hakim Mahkamah Syari'ah pada Tahun 1948. Dari karir demi karir sebagai hakim, sampailah ia pada posisi mahkamah tinggi yang disebut sebagai Mahkamah Isti'naf (pengadilan tingkat Mahkamah Agung).

\section{Konsep Pendidikan Taqiyuddin an Nabhani}

\section{Pendidikan Sebagai Interaksi Budaya, Ilmu dan Peradaban.}

Kebudayaan menurut perspektif an-Nabhânî dalam bahasa Arab disebut tsaqafah memiliki perbedaan substantif dengan ilmu. Ilmu adalah pengetahuan (ma'rifah) yang diperoleh melalui jalan mulahazhah (observasi), tajribah (eksperimen) dan istintaj (inferensial). Sebagai contoh, ilmu-ilmu alam dan semua ilmu-ilmu yang diraih melalui eksperimen serta beberapa pengetahuan non-eksperimen seperti berhitung, ekonomi perdagangan, teknik, dan perindustrian. Sedangkan tsaqafah adalah pengetahuan yang diperoleh dengan jalan akhbar (informatif), istinbath (derivatif) dan talaqqi (pertemuan secara langsung), seperti ilmu-ilmu sejarah, bahasa, dan filsafat. ${ }^{3}$

\footnotetext{
${ }^{2}$ Wamy, Gerakan keagamaan dan Pemikiran, Akar Idiologis dan Penyebarannya.

3 Taqiyuddin an-Nabhânî, as-Syakhsiyah a;-Islamiyah (Libanon: Dar al-Ummah, 1994), 262-263.
} Kalau memperhatikan lebih lanjut, kita akan lihat bahwa hakikatnya ilmu bersifat universal dan menyeluruh kepada seluruh umat tanpa ada pengkhususan kepada umat tertentu, siapapun berhak memilikinya. Berbeda dengan tsaqafah (kebudayaan), ada yang bersifat khas dan spesifik, sehingga setiap umat memiliki tsaqafah yang berbeda dengan umat lain, dan ada tsaqafah yang bersifat umum, dalam artian bersifat universal seperti halnya bisnis, ekonomi. Tsaqafah yang pertama inilah tidak bisa dikompromikan dengan tsaqafah lain. Tsaqafah Barat khusus untuk orang Barat, dan tsaqafah Islam khusus untuk orang-orang Islam. 
Cukup menarik pengklasifikasian yang dilakukan an-Nabhânî di atas tentang pengetahuan yang bersumber dari ilmu (sains) dan pengetahuan yang bersumber dari budaya. Pengetahuan yang didapat dari ilmu merupakan pengetahuan yang universal, terbuka, dan milik bersama semua manusia. Hanya saja, perlu dipertegas mana "universal" pengetahuan yang bersumber dari sains dan ketidak-universalan pengetahuan yang bersumber dari budaya.

Secara ontologis ilmu itu universal dan bebas nilai. Nabi sendiri telah menginstruksikan dalam haditsnya bahwa ilmu adalah mutiara umat Islam yang hilang. Maka di manapun diketemukan maka raihlah mutiara itu. Akan tetapi dari sisi aksiologinya, ilmu itu kemudian menjadi perdebatan yang belum berakhir, apakah bebas nilai atau tidak. Tetapi umumnya orang sepakat (dan kemungkinan besar merupakan yang paling benar) bahwa ilmu secara aksiologis tidak bersifat netral dan subyektif.

Demikian pula dengan tsaqafah (kebudayaan), yang apabila diposisikan sebagai pengetahuan dalam aspek aksiologinya, dan hanya bersifat khusus kepada setiap umat atau masyarakat tertentu, maka bagi umat dan masyarakat lainnya sulit untuk bisa melaksanakannya, karena bertentangan dengan nilai-nilai filosofis umat dan masyarakat tersebut. Akan tetapi, apabila tsaqafah (kebudayaan) itu dipandang dari aspek ontologisnya, maka akan lebih bersifat universal, fleksibel dan terbuka. Seperti ilmu fiqih, ilmu tafsir Alqur'an, ilmu tauhid, dan semua ilmu ilmu tersebut dibangun dengan nilai-nilai filosofis Alqur'an, sehingga pelaksanaannya hanya kepada orang Islam, dan sebaliknya kedudukan ilmu tauhid, hadist, dan Alquran sebagai objek dan ilmu yang murni, maka ia bersifat objektif, fleksibel dan terbuka untuk siapa saja.

Adapun peradaban menurut an-Nabhânî harus dibedakan antara peradaban dengan

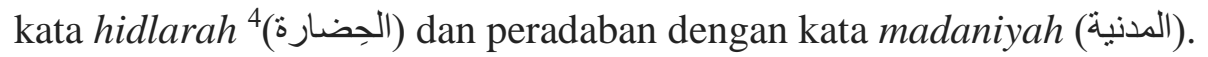

Hadlarah $^{5}$ didefinisikan sebagai kumpulan persepsi atau pemahaman tentang kehidupan yang bersifat khas, sesuai dengan pandangan hidup. Sedangkan madaniyah ${ }^{6}$ adalah segala sesuatu yang bersifat kebendaan dan materi yang terindah untuk dapat digunakan dalam berbagai aspek kehidupan. ${ }^{7}$

${ }^{4}$ Penulis lebih cenderung menggunakan kata Hidlarah daripada Hadlarah karena merujuk dalam Kitab Lisan al-Arab Ibnu Manzur disebutkan dengan Hidlarah, dengan berbaris kasrah dan tidak ditemukan kata Hadlarah kecuali pada ucapan al-Qattami فأي رجال بادية ترانا * فمن تكن الحضارة أعجبت

Ibnu Khaldun dalam kitab Muqaddimah nya juga menggunakan kata al-Hidlarah.

${ }^{5}$ Secara etimologis, kata Hidlarah berasal dari beberapa kata derivative (isytiqaq). Dalam Lisan alArab, Ibnu Manzur menyebutkan sesuai dengan urutannya; hadlira حضر : ada dan tidak pergi al-Hadlar: الحضر lawan dari kata al-Badwi, al-Hâdliru الحاضر orang yang bermukim di kota, الحِضارةal-Hidlarah; bermukim atau berdiam di kota. Al-Hudlur الحضور berada di tempat lawan ghaib, الحاضرة al-Hadlirah; wilayah yang besar atau lingkungan yang luas, al-Hadlirah الحضيرة kumpulan suatu kaum (jamaah) yang terdiri dari tujuh sampai delapan orang. Lihat Abu al-Fadhl Jamaluddin Muhammad ibn Mukrim Ibn Manzur, Lisan al-Arab, Jilid 4 (Beirut: Dar Shadir, 1990), 196-199. atau kata دان

${ }^{6}$ Madaniyah secara leksikografis berasal dari kata (madana) artinya berdiam di suatu tempat

(dâna) artinya tunduk dan taat. Oleh sebab itu, madinah dalam pandangan Islam adalah hasil dari adanya nilai-nilai kehidupan manusia yang lahir dari akidah Islamiyah bukan nilai yang lahir dari pendudukan madinah seperti nilai etika, sistim, produksi, hubungan social, dan politik. Berbeda dengan madinah dalam mafhum Barat yang dianggap sebagai sumber lahirnya nilai-nilai tersebut. Nashr Muhammad Arif, alHadlarah, ats-Tsaqafah, al-Madaniyah; Dirasat li Sirat al-Mushtalah wa Dalalah al-Mafhum (Virginia: alMa'had al-Alam al-Fikri al-Islami, 1994), 52.

7 Abdul Qadir Zallum, Mengenal Sebuah Gerakan Islam di Timur Tengah, terj. Abu Afif dan Nur Kholish (Surabaya: CV El-Fath, tt), 63. 
Hadlarah memiliki sifat khas tertentu sedangkan madaniyah adalah yang bersifat khas dan ada yang bersifat umum. Yang bersifat khas adalah madaniyah yang dihasilkan dari hadlarah seperti patung, gambar. Adapun bentuk-bentuk madaniyah yang merupakan produk kemajuan sains dan perkembangan teknologi adalah madaniyah yang bersifat umum dan universal, tidak terbatas hanya kepada umat tertentu. ${ }^{8}$

Setiap umat ataupun bangsa memiliki peradaban (hadlarah) tertentu yang lahir dari mafahim (persepsi) kolektif tentang kehidupan. Oleh karena itu, umat Islam haram hukumnya untuk mengadopsi dan mengembangkan peradaban selain peradaban yang berasaskan Islam. Seperti mengadopsi dan mengemban peradaban Barat. Karena ia merupakan peradaban sekuler yang dibangun berdasarkan prinsip pemisahan agama dan kehidupan, di mana Hakikat kehidupan hanya dinilai sebagai ajang untuk meraih manfaat dan masalah duniawi untuk mendapatkan kenikmatan jasmani dan kepuasan naluri. Sedangkan peradaban Islam dibangun di atas landasan Aqidah Islamiyah atau keimanan kepada Allah SWT. ${ }^{9}$

Uraian di atas dapat dipahami bahwa an-Nabhânî mencoba memberikan terminologi khusus istilah peradaban yang bersifat umum yang disebut civilization di dunia Barat, yang sementara dalam literatur bahasa Arab istilah hadharah dan madaniyah keduanya dipakai untuk menerjemahkan makna civilization. Bahwa civilization ada yang berbentuk kumpulan pemahaman/persepsi suatu masyarakat itulah hadharahnya dan ada sebagai bentuk materi yang dimanfaatkan manusia dalam kehidupan itulah Madaniah.

Peradaban dalam makna pertama inilah dianggap bersifat khas. Setiap umat atau bangsa memiliki kumpulan pemahaman atau persepsi khusus di dalam menyikapi kehidupannya dan persepsinya itu tidak terlepas dari pengaruh budaya, ide-ide, dan ideologis yang tidak mungkin dikompromikan secara damai. Karena persepsi itu adalah bagian dari nilai yang terkandung dalam masyarakat tertentu sebagai hasil bentukan tradisi masyarakat itu sendiri yang dijaga dan dipertahankan berdasarkan pemahaman mereka. Sehingga peradaban dalam makna ini berjalan sendiri-sendiri karena berkaitan dengan pandangan hidup dan ideologi. Sedangkan peradaban dalam konteks madania adalah hasil kreativitas dan karya masyarakat yang berwujud materi. Sehingga sah-sah saja melakukan lintasannya.

Pemikiran-pemikiran an-Nabhânî di atas, baik masalah ilmu dan budaya maupun peradaban dalam konteks hadlarah dan madaniyah memberikan jawaban bahwa sesungguhnya dia menyadari bahwa bagaimanapun manusia tidak akan pernah bisa menghindar dari interaksi dengan manusia yang lain untuk memenuhi kebutuhan hidupnya, apalagi kemajuan ilmu pengetahuan dan peradaban dunia sekarang ini berada dalam pangkuan Barat. Umat Islam pasti dan harus berinteraksi dengan Barat, baik

${ }^{8}$ Taqiyuddin an-Nabhânî, Nizham al-Islam (t.tp: Hizbut Tahrir, 2001), 63. Membahasakan peradaban dengan hidlarah pada hakikatnya membicarakan jalan umat manusia dalam mencari kehidupannya. Setiap umat memiliki kepribadian khusus, karakteristik berbeda, dan cakrawala yang khas. Oleh sebab itu, satu masyarakat berbeda dengan masyarakat lainnya. Perbedaan ini dilatarbelakangi oleh factor pemikiran, perasaan yang dimilikinya, sistim, serta pandangan hidup yang diembannya. Dari sinilah lahir suatu hidlarah.

${ }^{9}$ Taqiyuddin an-Nabhânî, Nizham al-Islam, 64. Adapun peradaban dalam konteks madaniyah ada dua bentuk, apabila bersumber dari hidlarah seperti gambar dan patung, maka juga tidak boleh diadopsi ke dalam Islam karena bertentangan dengan akidah Islam. Sedangkan madaniyah yang merupakan produk kemajuan sains dan perkembangan teknologi, maka umat Islam boleh saja mengadopsinya ke dalam Islam. 
pemikiran, ilmu pengetahuan, ataupun budaya, apabila ingin menyusun kembali batubata peradaban yang telah berserakan. Hanya saja umat Islam dituntut untuk memilah dan memilih peradaban yang tidak bertentangan dengan nilai dasar Alquran dan sunnah Nabi sebagai konsep dasar ilmu pengetahuan, peraturan/hukum ataupun pandangan hidup.

Hakikat peradaban ilmu dan budaya yang dikemukakan an-Nabhânî juga menjadi jawaban bahwa anti Barat yang dikumandangkan di negeri-negeri Arab-Islam adalah Barat sebagai imperialis yang telah menghancurkan sendi-sendi kehidupan umat Islam, baik penjajahan dalam bentuk fisik material maupun penjajahan dalam bentuk maknawiideologi. Sebab itu an-Nabhânî melakukan aktivitas politik dengan pertarungan pemikiran serta mendidik (tatsqif) umat Islam dengan pendidikan politik untuk menumbuhkan pemahaman dan kesadaran yang tinggi tentang Islam; yaitu dengan membangun sebuah kekuatan politik untuk melawan Barat-Imperialis. Dari sinilah kemudian an-Nabhânî mengkonsepkan satu konsep pemerintahan yang sesuai dengan norma-norma ajaran Islam.

\section{Konsep pendidikan Islam an-Nabhânî.}

Berbicara tentang konsep pendidikan berarti membicarakan eksistensi atau hakikat manusia dalam mengelola kehidupannya, karena manusia adalah subjek sekaligus objek pendidikan. Oleh karena itu, untuk mengawali uraian konsep pendidikan an-Nabhânî, akan diuraikan terlebih dahulu hakikat penciptaan manusia.

Manusia apabila dilihat dari sosok dirinya, beban dan tanggung jawab yang diamanatkan kepadanya merupakan karya Allah SWT yang paling istimewa. Ia dilengkapi dengan unsur jasmani dan unsur rohani serta mendapat amanat yang mulia sebagai "Abdun"10 dan "Khalifah"11. Itu karena manusia adalah makhluk yang di muliakan Tuhan dan diberi kesempurnaan dibandingkan dengan makhluk lainnya, serta makhluk yang diciptakan Tuhan dalam bentuk yang sebaik-baiknya. Dari sini dapat dipahami bahwa manusia adalah makhluk sang Khaliq yang diciptakan untuk mengemban dua amanat mulia, mengabdi kepada Penciptanya dan sebagai mandataris Tuhan untuk menjaga dan melestarikan alam. Amanat ini menempatkan manusia menjadi makhluk yang mulia dan dimuliakan, dan dibentuk menjadi makhluk yang paling sempurna ciptaannya, dilengkapi dengan jasad (materi), ruh, dan akal selama menjalani hidup dan kehidupannya di alam raya ini.

Manusia menurut an-Nabhânî memiliki hubungan yang tidak terpisahkan dengan alam semesta (al-Kaun), dan kehidupan (al-Hayat). Ketiganya merupakan unsur materi, bukan ruh dan bukan juga campuran materi dan ruh. Manusia sebagai unsur materi artinya sesuatu yang dapat dijangkau dengan indra, apakah materi itu diartikan sebagai sesuatu yang menempati ruang dan memiliki massa, atau diartikan sebagai tenaga yang dapat menggerakkan, baik materi itu abstrak maupun kongkrit. ${ }^{12}$

${ }^{10}$ Seperti disebutkan dalam firman-Nya وما خلقت الجن والإنس إلا ليعبدون dan tiadalah Aku ciptakan jin dan manusia kecuali untuk beribadah kepada-Ku. (Q.S.51:56)

11 و إذ قال ربك للملائكة إنى جاعل فى الأرض خليفة Dan Tuhanmu berkata kepada malaikat sesungguhnya akan Aku ciptakan khalifah di muka bumi ini (Q.S.2:3). Lihat Jalaluddin, Teologi Pendidikan (Jakarta: Raja Grafindo Persada, 2001), 12.

${ }^{12}$ Taqiyuddin an-Nabhânî, Pokok-pokok Pikiran Hizbut Tahrir, terj. Abu Afif (Indonesia: Thariq alIzzah, 1993), 12. 
An-Nabhânî membedakan manusia dari unsur akal, ruh, dan jasadnya. Manusia dengan bentukan dirinya adalah materi yang keberadaannya sebagai makhluk ciptaan Allah. Sedangkan tubuh adalah kesadaran hubungan manusia dengan Allah, bukan ruh dalam makna sirrulhayat (rahasia hidup/ nyawa) atau makna lain yang disebutkan dalam Alquran. Sebab itu, manusia bukanlah campuran dari materi dan ruh, ruh tidak berkaitan dengan bentukan manusia, buktinya, orang kafir adalah manusia yang memiliki nyawa tetapi karena tidak mengenal hubungannya dengan Allah, yang dianggap tidak memiliki ruh. Sebagaimana halnya hewan memiliki nyawa tetapi orang tidak pernah mengatakan bahwa hewan mempunyai aspek rohani. Ini artinya dengan pengertian kerohanian atau aspek rohani yang ada dalam diri manusia bukan dalam arti nyawa, tetapi dalam makna yang lain yaitu kesadaran hubungan manusia dengan Allah. ${ }^{13}$

Selain ruh, manusia memiliki akal dan jiwa. Akal adalah "lafaz yang mempunyai makna memahami dan menetapkan sesuatu.."14. Eksistensi akal memiliki peranan dalam karya, karsa dan cipta manusia. Ilmu, funûn (pengetahuan profesional), dan segala bentuk budaya adalah buah dari pikiran, dan pikiran adalah buah dari akal. Akar yang melahirkan realitas berfikir manusia, dan dari berpikirnya akan melahirkan budaya dan ilmu pengetahuan. ${ }^{15}$

Itulah pengetahuan yang dihasilkan dari akar (idrak al- 'Aql), dan dengan akal itulah manusia dibedakan dengan binatang, meskipun binatang juga menghasilkan pengetahuan akan sesuatu, tetapi hanya dengan perasaan (idrak asy-Syu'ur). Antara manusia dengan binatang memiliki kesamaan karena perasaan dan dibedakan karena akalnya. Pengetahuan akal (idrak al-'Aql) dengan pengetahuan perasaan (idrak asSyu'ur) berbeda. Akal lahir dari empat komponen yang telah disebutkan sebelumnya, sedangkan perasaan lahir dari naluri (gharizah) dan kebutuhan jasmani [hajat al-

13 Taqiyuddin an-Nabhânî, Pokok-pokok Pikiran Hizbut Tahrir, 12-13

14 Taqiyuddin an-Nabhânî, as-Syakhsiyah al-Islamiah (t.tp: t.p, t.t), 15.

${ }^{15}$ Proses akal hingga melahirkan persepsi (mafahim) mesti melalui empat komponen: ada fakta atau objek, indra, otak, dan pengetahuan atau informasi sebelumnya. Dalam prosesnya akal bukanlah in'ikas (refleksi) benda kepada panca indra atau sebaliknya, karena setiap gerak refleksi memerlukan qabiliah (tendensi). Seperti refleksi yang ditimbulkan cermin atau sinar memantulkan tendensi balikan. Hakekat akal manusia adalah ihsas (sensibility) atau pemindahan gambaran suatu fakta (obyek) yang dilakukan panca indra ke dalam otak yang disertai ma'lumat sabiqah (pengetahuan sebelumnya) tentang obyek tersebut. Ibid. hal.15. Akal terbentuk dari ikatan fakta dengan informasi sebeumnya, atau sebaliknya yang kemudian diproses oleh otak secara sensible sehingga dapat memunculkan persepsi. Maka dengan akalnya, manusia akan memahami perbedaan antara kata dan kalimat, memahami perbedaan antara panas dan dingin. Lihat Taqiyuddin anNabhânî, as-Syakhsiyah al-Islamiyah, op.cit. hal.13. Akal tidak akan melahirkan persepsi dan tidak akan sampai kepada suatu pemahaman tanpa ada informasi sebelumnya. Misalnya, ketika seorang anak diperlihatkan singa, gajah dan anjing atau gambar, atau gambar ketiga binatang itu, di mana anak tersebut belum pernah mendapat informasi sebelumnya tentang gajah, singa dan anjing, maka ia tidak akan mampu mengindentifikasi dan memahaminya, meskipun pada diri anak ada otak, indra dan ada fakta/binatang. LIhat Taqiyuddin an-Nabhânî, Pokok-pokok Pikiran Hizbut Tahrir, 7-18. 
'Udawiyyah]. ${ }^{16}$ Akal menghasilkan persepsi (mafahim) sedangkan perasaan menghasilkan kecenderungan [muyul] untuk memenuhi kebutuhan. ${ }^{17}$

Syakhsiyah manusia tebentuk dari pengindraan realitas yang dikaitkan (rabht) dengan informasi sebelumnya, kemudian memutuskan realitas untuk memenuhi kebutuhan hidupnya atau mempertahankannya. Uang yang banyak adalah realitas yang diihsas otak dari hasil informasi sebelumnya menyimpulkan manfaat uang tersebut dapat dipergunakan untuk kebutuhan jasmani atau pun nalurinya. Maka apabila persepsi (pemahaman) dilandasi dengan keimanan maka ia akan berusaha mencari uang dengan cara yang halal, tetapi apabila tidak dilandasi dengan iman maka ia menggunakan segala cara untuk mendapatkannya.

Uraian di atas menggambarkan suatu konsep bahwa manusia memiliki dua potensi dasar pemahaman yang membentuk kepribadiannya yaitu akal dan jiwa. Akal sangat berperan dan menjadi penentu pemahaman seseorang, dari pemahamannya kemudian melahirkan suatu perbuatan. Sehingga apapun bentuk perbuatan manusia adalah hasil dari persepsi dan keputusan akalnya. Maka tidak ada orang yang berbuat sesuatu secara sadar di luar dari hasil keputusan akalnya. Muhammad Taqyuddîn an-Nabhânî memiliki persepsi rasional yang khas ketika menempatkan informasi sebelumnya sebagai bagian dari komponen akal yang menyatu, tidak dikatakan akal tanpa ada informasi sebelumnya. Sebaliknya juga, manusia tidak mampu mendapatkan persepsi hanya bergantung pada informasi sebelumnya. Dengan demikian, Alquran sebagai wahyu Allah yang diinformasikan oleh Rasul-Nya sebagai informasi yang memuat konsep dasar hokum dan peraturan manusia adalah penyempurna aktifitas akal dalam mengambil suatu persepsi, oleh sebab itu manusia tidak bisa menemukan suatu persepsi kebenaran hanya dengan informasi yang dibawah Rasul. Maka dapat disimpulkan bahwa akal dalam pandangan an-Nabhânî bersifat kulli (universal dan general) sedangkan informasi yang dibawa Rasul adalah juz'i (parsial).

Pemahamannya tentang akal seperti di atas kemudian an-Nabhânî membangun prinsip-prinsip akidah dengan akidah aqliyah (keyakinan rasionalitas). Bahwa manusia

16 Al-Gharizah adalah potensi yang terdapat dalam diri manusia yang mendorongnya bertendensi dengan segala sesuatu yang ada di sekitarnya, baik berbentuk materi maupun perbuatannya, ataupun bertendensi menahan diri dari hal tersebut. Penampakan naluri itu timbul karena adanya indikasi internal. Seperti naluri cinta kepada wanita muncul karena melihat wanita. Setiap manusia memiliki minimal tiga macam naluril; pertama gharizah al-Baqa' (naluri mempertahankan diri). Manusia dengan gharizah Baqa'nya akan selalu menjaga dan mempertahankan diri dari segala yang merugikan, sehingga ia berusaha untuk memiliki dan mempertahankan hak miliknya. Oleh sebab itu, manusia akan selalu cinta dengan kekayaan, cinta kekuasaan, dan selalu ingin memiliki. Kedua, gharizah al-Na'u', naluri ini mendorong pada penjagaan manusia karena sifat basyariyahnya, artinya naluri saling menjaga sebagai makhluk biologis. Seperti kecenderungan untuk menyukai lawan jenis, menolong orang yang membutuhkan. Ketiga, gharizah al-Tadayyun (naluri beragama). Setiap manusia memiliki naluri untuk mensucikan apa yang dirasakan memiliki kekuatan terhadap alam, manusia dan kehidupan. Siapa pun pasti memiliki potensi untuk mensucikan sesuatu yang dianggap memiliki kekuatan (Ahmad 'Athiat al-Thariq, Dirasat Fikriyah fi Kaefiyat al-Amal li taghyir Waqi' al-Ummah wa Inhadhiha (Libanon: Dar al-Bayarik, 1996), 67-68.

Al-Hajat al-Udawiyah adalah kekuatan/energy kehidupan yang bersifat dharuri yang harus dipenuhi secara mutlak bagi diri manusia, karena apabila tidak dipenuhi dalam jangka waktu tertentu dapat berakibat kehancuran manusia. Seperti kebutuhan untuk makan, minum, tidur dan istirahat. Kebutuhan ini penampakannya timbul dari dalam diri manusia. Lihat Ahmad Athiat, op.cit. hal.65 dan Taqiyuddin anNabhânî, Pokok-pokok Pikiran Hizbut Tahrir, 19.

17 Taqiyuddin an-Nabhânî, Pokok-pokok Pikiran Hizbut Tahrir, 13 
meyakini Tuhan tidak bisa tanpa melalui akalnya. Bahkan an-Nabhânî katakan bahwa adanya Tuhan Pencipta karena adanya makhluk ciptaan, apabila tidak ada makhluk (ciptaan) maka tidak ada khaliq (pencipta), dan pencipta tanpa ada ciptaan akan menjadi naqis (tidak sempurna eksistensinya). ${ }^{18}$

Dari pemikiran an-Nabhânî di atas dapat dikonklusikan bahwa, dalam proses pembentukan pribadi anak didik, akal dan jiwanya merupakan dua potensi dasar yang harus dibina, dididik, dan dikembangkan dengan baik, sebab apapun bentuk kepribadian anak didik nantinya sangatlah ditentukan oleh pemahamannya. Artinya bahwa anak didik yang dibina dan diajarkan dengan ajaran Islam maka akan membentuk pada dirinya pemahaman yang Islami, sehingga jiwanya pun akan selalu diikat dengan pemahaman tersebut. Ketika manusia telah terbentuk kepribadiannya yang Islami, maka ia akan selalu dihiasi dengan ruh atau kesadaran akan hubungannya dengan Allah SWT.

Pandangannya tentang hakekat manusia menunjukkan pemahamannya dalam pendidikan hanya menekankan pada pendidikan akal dan pendidikan jiwa. Ini berbeda dengan teori pendidikan Islam yang menetapkan empat aspek pendidikan; yaitu akal, jiwa, ruh, fisik. Pembatasan pada aspek jiwa dan akal saja karena an-Nabhânî menganggap kepribadian manusia hanya terbentuk akal dan jiwa, sedangkan jasad tak ubahnya wadah yang dikendalikan oleh unsur lain sehingga tidak perlu dididik dan dibina, karena tidak akan berpengaruh kepada kepribadian. Adapun ruh sendiri adalah kesadaran akan hubungannya dengan Allah, artinya an-Nabhânî melihat ruh sebagai hasil dari pribadi yang telah memiliki akal dan jiwa yang beriman kepada Allah. Dari dua potensi dasar manusia inilah awal konstruksi konsep pendidikannya.

\section{Paradigma Pendidikan (Islam) an-Nabhânî.}

Berbicara tentang paradigma pendidikan menurut perspektif an-Nabhânî dapat dicermati dan dianalisa - selain dari pandangan an-Nabhânî bahwa pendidikan sebagai interaksi budaya, ilmu dan peradaban seperti dipaparkan di atas - dari dua aspek utama yaitu aspek pemaknaan pendidikan itu sendiri secara filosofis dan aspek sistem pendidikan yang dijabarkan berdasarkan pemaknaan pendidikan tersebut. Kedua aspek akan dikemukakan secara jelas berikut ini:

\section{Makna Filosofis Pendidikan Islam.}

Hampir tidak ditemukan definisi khusus pendidikan Islam dalam kitab-kitab yang ditulis oleh an-Nabhânî. Tidak satu pun pasal dari dua belas pasal dalam kitab-kitabnya yang secara jelas memberikan definisi pendidikan Islam, kecuali beberapa pemikiran pendidikan yang bisa dijadikan dasar untuk mendefinisikan konsep pendidikannya. Beliau menyebutkan dalam bukunya bahwa "strategi pendidikan adalah pembentukan pola pikir dan pola jiwa yang Islami ${ }^{19 " . ~ M e n u r u t n y a ~ l e m b a g a ~ p e n d i d i k a n ~ m e m i l i k i ~}$ peran signifikan dalam mendidik dan mencerdaskan peserta didik dan memberinya ilmu. Namun sekolah sebagai salah satu institusi pendidikan bagi an-Nabhânî memiliki keterbatasan out come karena hanya mampu mendidik seorang individu tertentu, maka sekalipun sekolah berbentuk sebuah komunitas kecil, tetap saja bersifat individual, sehingga pendidikan yang dihasilkan juga bersifat individual. ${ }^{20}$

\footnotetext{
18 Taqiyuddin an-Nabhânî, Pokok-pokok Pikiran Hizbut Tahrir, 37.

19 Taqiyuddin an-Nabhânî, Muqaddimah ad-Dustur (t.tp: t.p., 1963), 414.

${ }^{20}$ Taqiyuddin an-Nabhânî, Nizham al-Islam, 52.
} 
Sebab itu an-Nabhânî lebih memilih bentuk organisasi kepartaian sebagai institusi pendidikan dan pembinaan. Pembinaan partai bersifat jamaah bukan individual. Meskipun yang dididik dalam partai adalah individu, namun individu tersebut adalah bagian dari jamaah dan masyarakat yang integratif. Institusi sekolah berbeda dengan partai/organisasi ini dalam tiga hal:

1). Sekolah bersifat rutin dan monoton sehingga tidak membentuk masyarakat, sedangkan partai berkembang secara dinamis tanpa ada mekanisme rutin sehingga dapat membentuk masyarakat.

2). Sekolah menekankan pendidikan individu untuk mempengaruhi jamaah (orang banyak) sehingga lebih bersifat individual, sedangkan organisasi partai mendidik jamaah untuk mempengaruhi individu.

3). Sekolah mempersiapkan perasaan secara parsial pada individu untuk mempengaruhi perasaan jamaah, sementara partai mempersiapkan perasaan secara menyeluruh dalam jamaah untuk mempengaruhi perasaan individu-individunya. ${ }^{21}$

Penjelasan an-Nabhânî di atas memberikan gambaran bahwa, an-Nabhânî mencoba menjelaskan strategi dan sistem khusus dalam membangun sebuah paradigma pendidikan sebagai upaya dan proses pembentukan pola pikir serta pembentukan pola jiwa peserta didik. Dalam langkah strategisnya itu, an-Nabhânî lebih menempatkan masyarakat sebagai institusi yang ideal dalam pelaksanaan pendidikan, karena institusi tersebut bersifat dinamis, terbuka kepada seluruh umat tanpa ada perbedaan status terhadap peserta didik, sehingga siapapun boleh menjadi peserta didik tanpa ada aturanaturan formalitas yang terlalu mengikat. Sementara sekolah, sebagai lembaga pendidikan formal, meskipun an-Nabhânî tidak menafikan eksistensinya dalam pelaksanaan pendidikan, namun eksistensinya yang terpasung dengan aturan-aturan formalistik dan sempit, menyebabkan pendidikannya tidak berjalan dinamis dan menjadikan peserta didik menjadi manusia yang individualis sehingga tidak mampu membentuk sebuah komunitas umat yang kuat.

Individualisme sebagai nilai yang telah melembaga dalam sekolah juga dikritik habis oleh pemikir-pemikir Amerika Latin seperti Ivan Illich Paulo Freire. Illich malah menuding bahwa sekolah sebagai sarana umum yang palsu, sehingga ia mengkampanyekan tindakan revolusioner untuk melucuti sekolah dari kemapanannya sebagai jalan tol melepaskan pendidikan dari titik ekstrim dan spektrum kelembagaan yang menyebabkan banyak orang bunuh diri secara spiritual. ${ }^{22} \mathrm{Hal}$ itu terjadi karena sekolah dituduh Paulo Freire, ${ }^{23}$ yang merupakan produk kapitalisme yang licik tidak difungsikan sebagai elemen perubahan sosial, Tetapi malah dimanfaatkan sebagai elemen praktis untuk mereproduksi ideologi borjuis.

Bagi an-Nabhânî, Ivan Illich, Paulo Freire, meskipun starting point mereka berbeda, namun secara umum mereka menyadari sekolah sebagai lembaga pendidikan yang berbaju ideologi kapitalis, melembagakan bentuk individualisme yang mapan. Akibatnya nilai-nilai persamaan hak mendapatkan pengajaran dengan monopoli bagi

\footnotetext{
${ }^{21}$ Taqiyuddin an-Nabhânî, Nizham al-Islam, 54.

${ }^{22}$ Ival Illich, Bebaskan Masyarakat dari Belenggu Sekolah (Jakarta: Yayasan Obor Indonesia, 2000),

${ }^{23}$ Paulo Freire, Sekolah Kapitalisme yang Licik (Yogyakarta: LKiS, 2001), 42.
} 82. 
kelas-kelas tertentu. Secara khusus, bagi an-Nabhânî pendidikan tidak sekedar pembinaan yang parsial dan terbatas kepada individu-individu tertentu dan untuk menghasilkan manusia-manusia yang individualis, lebih dari itu, pendidikan merupakan pembinaan yang bersifat komprehensif kepada seluruh umat. Umat dididik tidak sekedar proses transfer ilmu pengetahuan dan budaya dalam bentuk penguasaan prinsipprinsip ilmu sebagai sebuah objek kajian ilmiah untuk kepentingan individu, tetapi umat diri untuk membangun persepsi dan memiliki integritas kepribadian yang tinggi dalam membangun sebuah jama'ah atau komunitas masyarakat.

Pandangan an-Nabhânî di atas dan pandangannya tentang hakikat manusia yang disebutkan sebelumnya dapat ditarik satu pandangan baru bahwa, pendidikan Islam menurut an-Nabhânî adalah proses pembinaan dan pengembangan akal dan jiwa peserta didik sehingga dapat memiliki kepribadian dengan kesadaran akan hubungannya kepada Allah SWT. Sehingga dapat membentuk suatu jamaah atau masyarakat yang ideal.

Selanjutnya, agar lebih memahami pandangan an-Nabhânî tentang dasar pendidikan, maka ada baiknya dikemukakan pandangan-pandangan dasar pendidikan atau paradigma dasar dalam pengembangan pendidikan Islam. Menurut Muhaimin, ada tiga paradigma pengembangan pendidikan; pertama, Paradigma Formisme, yaitu paradigma yang berimplikasi terhadap pengembangan pendidikan Islam yang lebih berorientasi pada keakhiratan dan tidak mementingkan aspek duniawi, ilmu ilmu sains dan tidak terlalu dipentingkan. Fokus utamanya adalah ilmu-ilmu agama yang merupakan jalan pintas menuju akhirat. ${ }^{24}$

Kedua, Paradigma Mekanisme. Sesuai dengan namanya mekanisme (dari mechanism), paradigma ini memandang pendidikan sebagai mesin yang bekerja sendiri sendiri, sebagai penanaman dan pengembangan seperangkat nilai kehidupan, yang berjalan berdasarkan dan bergerak sesuai fungsi dan perannya dalam menghadapi kehidupan yang multi-dimensi. Seluruh nilai kehidupan ini saling berhubungan secara horizontal-lateral, lateral-sekuensial, atau vertikal -linear. ${ }^{25}$

Ketiga, Paradigma Organisme, dua yaitu paradigma yang berpandangan bahwa pendidikan Islam adalah suatu sistem yang membentuk satu kesatuan atas komponenkomponen yang berusaha mengembangkan pandangan dan semangat hidup (weltanschaung) Islam dalam dimanifestasikan untuk dimanifestasikan dalam sikap dan keterampilan hidup. ${ }^{26}$

Ketiga paradigma di atas meskipun berbeda pemahaman tentang hakikat pendidikan Islam dan pengembangannya, namun kesemuanya tetap memahami sistem pendidikan Islam sebagai upaya menggiring manusia untuk berkreasi, dan mengembangkan kreativitas berfikirnya sehingga mampu mencapai kesempurnaan sebagai manusia berdasarkan kerangka nilai Wahyu dan ideologi Islam. Mengembangkan kualitas diri sesuai dengan normativitas ajaran wahyu yang permanen.

Sementara itu, pandangan an-Nabhânî sendiri tentang paradigma pendidikan atau dasar pendidikan, bahwa "Kurikulum pendidikan wajib berasaskan dengan Aqidah

${ }^{24}$ Muhaimin, Paradigma Pendidikan Islam (Bandung: Remaja Rosdakarya, 2002), 41.

${ }^{25}$ Muhaimin, Paradigma Pendidikan Islam, 43.

${ }^{26}$ Muhaimin, Paradigma Pendidikan Islam, 46. 
Islam, materi pelajaran dan metode pembelajaran harus tersusun berdasarkan Aqidah Islam dan tidak boleh sedikitpun keluar dari asas tersebut." 27

Aqidah sebagai dasar kurikulum pendidikan Islam mencakup dua hal; pertama bahwa aqidah adalah sumber ilmu pengetahuan, yang ilmu pengetahuan memiliki kaitan langsung dengan akidah dan hukum syara' terpancar dari Aqidah Islam tersebut. Kedua, aqidah sebagai barometer ilmu pengetahuan yang tidak memiliki kaitan langsung dengan akidah dan hukum syara'. Pemilahan ilmu pengetahuan seperti ini dimaksudkan bahwa hanya ilmu pengetahuan yang tidak bertentangan dengan Aqidahlah yang dapat diterima sebagai pengetahuan yang netral, Sedangkan ilmu pengetahuan yang bertentangan dengan Aqidah Islam, maka tidak layak untuk diterima dan diamalkan. ${ }^{28}$

Mencermati pemikiran an-Nabhânî di atas, yang jika dikaitkan dengan paradigma dasar yang disebutkan Muhaimin, maka dapat dikemukakan bahwa an-Nabhânî memiliki paradigma pendidikan organisme, paradigma yang memandang pendidikan non-dikotomik. Hanya saja, paradigma pendidikan an-Nabhânî, didasari oleh asas akidah Islam yang tegas. Akidah Islam menjadi paradigma dasar kurikulum pendidikannya, paradigma dasar dalam artian menjadi sumber ilmu pengetahuan dan paradigma dasar dalam aspek sebagai tolak ukur menilai segala bentuk ilmu pengetahuan.

Akidah sebagai sumber ilmu pengetahuan dan sekaligus barometer ilmu pengetahuan merupakan bentuk klasifikasi terbatas yang dinyatakannya ke dalam ilmu-ilmu agama dan ilmu ilmu profan atau antara al-Ulum dan al-Funun. Klasifikasi ini (akan dibahas lebih lanjut) dapat dikaitkan dengan pemikirannya tentang perbedaan ilmu dan budaya sebagaimana disebutkan sebelumnya, bahwa pada dasarnya an-Nabhânî tidak menolak universalitas ilmu pengetahuan, hanya saja perlu ada batasan-batasan ideologis apakah ilmu itu bebas dari nilai budaya atau tidak, apakah bertentangan dengan akidah atau tidak. Singkatnya, bahwa akidah menjadi inti dasar kurikulum pendidikan. Materi dan metode pembelajaran akan terpancar dari akidah Islamiyah, sebagaimana sistem pendidikan yang telah dicontohkan Rasulullah SAW. dalam membimbing dan mendidik umatnya, baik pada periode Mekkah maupun pada periode Madinah.

Konsep pendidikan an-Nabhânî yang berasaskan dengan akidah Islam merupakan bagian dari ajaran gerakannya yang bercita-cita mengembalikan kemurnian ajaran Islam, dengan melaksanakannya secara menyeluruh. Hal tersebut merupakan responreaktif terhadap realitas kehidupan umat Islam pasca keruntuhan khilafah Islam yang telah terkontaminasi dengan paham-paham yang menyimpang dari ajaran Islam, baik ideologi liberal-kapitalis maupun komunis-sosialis yang telah merusak kemurnian ajaran Islam dan melumpuhkan Aqidah Islam.

Seperti disebutkan pada bab sebelumnya bahwa sistem pendidikan Islam telah terkontaminasi dan dicemari dengan pemikiran individualisme, materialisme dan nasionalisme yang menggandeng lewat imperialis dan misionaris. Sistem pendidikan Islam dipaksa untuk berkiblat ke Barat-kapitalis dan individualis. Akibatnya semangat menuntut ilmu sebagai wujud perintah Tuhan akhirnya terkikis habis, yang ada hanya

27 Taqiyuddin an-Nabhânî, Muqaddimah ad-Dustur, 411.

${ }^{28}$ Taqiyuddin an-Nabhânî, Muqaddimah ad-Dustur, 412. 
paradigma formil dan berorientasi duniawi. Realitas tersebut kemudian menggugah gerakan an-Nabhânî untuk membendung pengadopsian secara besar-besaran ilmu pengetahuan Barat apa ada proteksi dan filterisasi, dan berusaha mengembalikan hakikat pendidikan Islam sesuai dengan dasar dan tujuannya, sesuai dengan apa yang telah dicontohkan Rasulullah SAW. Sebagai wujud nyata upaya tersebut, an-Nabhânî berusaha membangun kembali sistem pendidikan Islam dengan berasaskan Aqidah Islam. Dengan kurikulum yang berdasarkan Aqidah Islam, kemudian menjabarkan seluruh tujuan sesungguhnya yang ingin dicapai dalam pendidikan Islam. Sementara rumusan tujuan pendidikan merupakan rumusan filsafat atau pemikiran yang mendalam tentang pendidikan. Karena tujuan utama pendidikan adalah terwujudnya nilai-nilai ideal yang terbentuk dalam diri manusia ${ }^{29}$. Sehingga tujuan pendidikan selalu diselaraskan dengan eksistensi manusia selaku subjek dan objek pendidikan. Tujuan apapun dari kegiatan kependidikan merupakan rumusan dari nilai-nilai filosofis dan pandangan hidup manusianya selaku objek pendidikan dalam rangka mewujudkan nilainilai ideal dalam dirinya selaku objek pendidikan.

Para ulama menggariskan tujuan pendidikan Islam secara variatif sesuai dengan penafsirannya masing-masing. Al-Ghazali misalnya, merumuskan tujuan pendidikan Islam sebagai upaya pembentukan kesempurnaan manusia yang tujuannya untuk lebih mendekatkan diri kepada Allah SWT dan untuk mendapatkan kebahagiaan dunia dan akhirat. ${ }^{30}$ Ibnu Qayyim al-Jauziyyah berpandangan bahwa tujuan pendidikan adalah menjaga fitrah (kesucian) manusia dan memberikan perlindungan kepadanya dari penyimpangan-penyimpangan syariat serta mewujudkan menjadi makhluk yang menghambakan diri kepada Allah SWT ${ }^{31}$. Sedangkan al-Qabisi berpendapat bahwa pendidikan Islam bertujuan untuk mengetahui ajaran agama Islam baik secara ilmiah maupun amalia. ${ }^{32}$

Semua pandangan di atas dapat dijelaskan bahwa secara umum mereka memiliki pemikiran yang sama bahwa tujuan pendidikan Islam merupakan rumusan dari nilainilai filosofis Islam, di mana pendidikan Islam diarahkan untuk mencapai tujuan Islam itu sendiri, yaitu realisasi nilai-nilai ideal Islami dalam kepribadian manusia yang dijiwai dengan iman dan taqwa.

An-Nabhânî mengkonsepsikan tujuan pendidikan sebagai upaya membentuk syakhsiyah islamiyah (kepribadian yang Islami) serta membekali manusia dengan ilmu dan pengetahuan yang berkaitan dengan urusan kehidupan. Metode pembelajaran dirancang untuk merealisasikan tujuan tersebut dan melakukan pencegahan terhadap metode pembelajaran yang menyimpang dari tujuan. ${ }^{33}$ Rumusan tujuan pendidikan anNabhânî tersebut menggambarkan secara umum tujuan pendidikannya tidak berbeda dengan tujuan pendidikan yang dirumuskan ulama Islam lainnya, yaitu implementasi nilai-nilai ajaran Islam yang tertuang dalam Alquran dan sunnah Nabi, di mana

${ }^{29}$ Arifin, Filsafat Pendidikan Islam (Jakarta: Bumi Aksara, 1996), 119.

${ }^{30}$ Fathiah Hasan Sulaeman, Mazhab fi at-Tarbiyah: Bahtsun fi al-Madzhab at-Tarbawi inda alGhazali (Kairo: Maktabah Nahdhah, 1964), 16.

${ }^{31}$ Hasan ibn Ali al-Hijazi, Manhaj Tarbiyah Ibnu Qayyim (Jakarta: Pustaka Kautsar, 2001), 83.

${ }^{32}$ Ali al-Jumbulati, Perbandingan Pendidikan Islam (Jakarta: Rineka Cipta, 1994), 36.

${ }^{33}$ Taqiyuddin an-Nabhânî, Muqaddimah al-Dustur, 414. 
pendidikan Islam diarahkan untuk mencapai tujuan Islam itu sendiri, yaitu realisasi nilai-nilai ideal Islam dalam pribadian manusia yang dijiwai dengan iman dan taqwa. Namun secara khusus tujuan pendidikan menurut nya adalah membentuk kepribadian Islam; yaitu kepribadian yang dibangun dengan akal dan jiwa yang terpancar dari aqidah Islam.

Sebagaimana dalam bahasan sebelumnya, an-Nabhânî memahami kepribadian manusia hanya terbentuk dari akal dan jiwa saja, ketika akan yang didasari dengan paradigma berfikir Islami dan jiwanya dibangun dengan pondasi ajaran Islam, maka tingkah lakunya pun akan sesuai dengan nilai-nilai ajaran Islam yang paripurna, sebaliknya, ketika cara berpikir didasari dengan paradigma berfikir yang materialis serta tertanam dalam jiwanya kecenderungan dan naluri untuk memiliki segala sesuatunya tanpa ada kontrol, maka hal tersebut juga akan mengarahkan tingkah laku dan perbuatan yang untuk menghalalkan segala cara demi terpenuhinya kebutuhan kebutuhan tersebut. Pembatasan kepribadian seseorang hanya terdiri dari akal dan jiwa merupakan faktor utama mengapa beliau hanya menitikberatkan pendidikan dan pengajarannya pada aspek akal dan jiwa saja.

Pendidikan akal dan pendidikan jiwa sebagai dua komponen utama pembentukan kepribadian dalam konsep pendidikan an-Nabhânî adalah pembatasan hakikat pendidikan Islam dan teori pendidikan Islam yang umumnya mencakup empat aspek; pendidikan akal, pendidikan jiwa, pendidikan ruh, dan pendidikan jasmani.. Pendapat an-Nabhânî tersebut didasari dengan anggapan bahwa fisik dan ruh dalam pemikirannya $b$ ukan komponen yang membentuk kepribadian manusia. Fisik hanyalah bentukan manusia selaku manusia dalam unsur materi, sedangkan ruh adalah kesadaran akan hubungan manusia kepada Allah, sehingga ruh dipahami sebagai hasil dari pemahamannya akan Allah. Masalahnya, mampukah dua komponen ini membentuk kepribadian manusia secara sempurna untuk bisa menunaikan amanat Tuhan selaku hamba dan khalifah.

Peniadaan pendidikan dalam konsep an-Nabhânî karena mendefinisikan ruh sebagai kesadaran hubungan manusia dengan Allah, sehingga pada prinsipnya bukan wilayah pendidikan. Berbeda dengan ulama-ulama Islam lainnya seperti Abdul Halim Mahmud $^{34}$ mendefinisikan ruh sebagai “... nama bagi nafsu yang mengaliri kehidupan, gerakan, upaya mencari kebaikan, dan upaya menghindarkan keburukan dalam diri manusia..." sehingga ruh merupakan aspek yang harus dididik dan dibina. Adapun pendidikan fisik secara unsur materi tidak bisa dipisahkan dari pendidikan akal dan jiwa, karena ketika komponen ini memiliki hubungan yang sangat erat. Meskipun jasmani tidak membentuk secara langsung kepribadian manusia, namun jasmani bisa mempengaruhi unsur akal dan jiwa. Otak misalnya sebagai salah satu komponen akal adalah jasmani manusia yang harus dididik dengan baik sehingga terhindar dari kerusakan atau penyakit. Apabila jasmani manusia tidak ikut terbina dan terdidik, maka dapat mengganggu aktifitas akal dan jiwa. Sebab itu, jasmani tidak bisa diabaikan sebagai objek pendidikan dalam membentuk kepribadian yang baik.

\footnotetext{
${ }^{34}$ Abdul Halim Mahmud, Pendidikan Ruhani (Jakarta; Gema Insani Press, 2000), 65.
} 
Kalaupun an-Nabhânî menyikapi aspek pendidikan akal dan pendidikan jiwa sebagai fondasi terbentuknya kepribadian manusia, hal ini besar kemungkinan karena beliau tidak melihat pendidikan dari segala dimensinya, di mana berbagai komponen memiliki hubungan yang berkaitan satu dengan lainnya. Bahkan kalau dikomparasikan pandangannya tentang jiwa dengan pandangan beberapa filosof, terdapat perbedaan yang tajam. Dari model paradigma berpikir an-Nabhânî tentang pendidikan Islam ini, pada gilirannya akan melahirkan sebuah konsep tentang sistem pendidikan (Islam), sebagaimana akan dibahas berikut ini.

\section{Sistem Pendidikan Islam}

Pada prinsipnya ilmu adalah satu-kesatuan yang utuh, semuanya berasal dari Allah SWT. Namun karena ilmu pengetahuan terus berkembang, objek ilmu pengetahuan semakin meluas dan cabang-cabang ilmu semakin banyak. Maka lahirlah klasifikasi atau penggolongan ilmu pengetahuan dari berbagai aspeknya. Bagi an-Nabhânî mempelajari segala ilmu pengetahuan adalah keharusan. Sumber dasar pandangannya adalah surat al-'Alaq, ayat satu dan lima bahwa Allah SWT telah memerintahkan menuntut ilmu secara mutlak (إقرأ باسم ربك الذى خلق) bacalah dengan nama tuhanmu yang telah menciptakan kemudian (علم الإنسان ما لم يعلم) yang telah mengajarkan manusia apa yang tidak diketahuinya. Ayat ini menurut an-Nabhânî merupakan lafaz 'aam (bersifat umum) yang mencakup semua macam ilmu pengetahuan. Sehingga mempelajari ilmu apa saja dibolehkan dalam Islam. ${ }^{35}$

Hanya perlu diperhatikan, yang apabila ilmu itu bertentangan dengan ajaran Islam atau dapat merusak aqidah, maka haram hukumnya untuk dipelajari ${ }^{36}$. Sebab itu, anNabhânî mengklasifikasikan ilmu pengetahuan dalam beberapa bagian. Sebagaimana beliau Sebutkan dalam bukunya kitab Dustur: "Antara ilmu-ilmu terapan seperti olahraga harus dipisahkan dengan ilmu-ilmu tsaqafah. Ilmu terapan diajarkan menurut kebutuhan dan tidak terikat dengan fase/jenjang pendidikan tertentu. Adapun ilmu-ilmu tsaqafah diajarkan kepada anak mulai dari tingkat dasar hingga tingkat menengah atas (Tsanawiyah) sesuai dengan strategi pendidikan dan tidak bertentangan dengan konsep dan hukum Islam. ${ }^{37}$

Klasifikasi tersebut dikarenakan ilmu pengetahuan tidak terlepas dari dua sumber pokok yang sama-sama saling mengikat dan pengaruhi yaitu; ilmu dan tsaqafah (wawasan). Ilmu adalah pengetahuan (ma'rifah) yang didapat melalui jalan observasi, eksperimen, dan inferensial. Sedangkan tsaqafah adalah pengetahuan yang didapat dengan jalan akhbar (informasi), istinbath (penyajian), dan talaqqi (pertemuan dan komunikasi), yaitu sebuah pengetahuan yang bersifat informatif, derivatif, dan perjumpaan secara langsung, seperti ilmu sejarah, bahasa, filsafat, dan ilmu pengetahuan yang tidak melalui eksperimen. ${ }^{38}$

Namun Aqidah Islam senantiasa menjadi asas dan parameter semua ilmu pengetahuan apabila ilmu pengetahuan bertentangan dengan prinsip-prinsip Aqidah Islam, maka tidak boleh diambil dan diyakini. Sebaliknya semua ilmu pengetahuan yang

\footnotetext{
35 Taqiyuddin an-Nabhânî, Muqaddimah al-Dustur, 396.

${ }^{36}$ Taqiyuddin an-Nabhânî, Muqaddimah al-Dustur, 417.

37 Taqiyuddin an-Nabhânî, Muqaddimah al-Dustur, 416-417.

${ }^{38}$ Taqiyuddin an-Nabhânî, as-Syakhsiyah al-Islamiyah, 262-263.
} 
tidak bertentangan dengan Akidah Islam maka harus diambil, bahkan menjadikan Aqidah Islam sebagai dasar kurikulum pendidikan adalah persoalan wajib bagi negara. ${ }^{39}$ Seperti ilmu filsafat dipelajari hanya sekedar untuk diketahui supaya bisa mengantisipasi dan menyingkap kebatilan kebatilannya, bukan untuk diamalkan. Karena Alquran sendiri telah menyebutkan pemikiran dan akidah non-Islam namun kesemuanya hanya menjelaskan kebatilannya, oleh karena itu, filsafat boleh dipelajari untuk mengcounter dan menyingkap kebatilannya. ${ }^{40}$

Mempelajari klasifikasi di atas, pada prinsipnya an-Nabhânî menilai ilmu pengetahuan bersifat universal, sinergis, dan bukan dalam tataran dikotomi. Klasifikasi yang sinergis untuk membentuk kepribadian Islam, dengan menata ontologi, epistemologi, dan aksiologi keilmuan yang di berlandaskan nilai-nilai Islam. Setiap dan siapa pun orangnya memiliki hak untuk mencari ilmu pengetahuan yang mencakup seluruh aspek kehidupannya. Pengklasifikasian dan pengisian jenis ilmu tersebut mengindikasikan bahwa an-Nabhânî tidak melihat adanya pertentangan dan perbedaan ilmu ilmu agama dengan ilmu-ilmu umum, apalagi menciptakan dikotomi negatif antara keduanya, karena ilmu apa saja boleh dipelajari. Beliau hanya melihat dari sisi sumbernya, apakah ilmu itu murni sebagai suatu sains atau ada pengaruh budaya-budaya tertentu atau terdapat pengaruh budaya yang bertentangan dengan ajaran Islam sehingga dapat mempengaruhi peserta didik.

Pemikirannya tersebut tidak membedakan eksistensi ilmu pengetahuan sebagai sesuatu yang boleh bahkan wajib untuk dipelajari, baik ilmu-ilmu agama sebagai ilmu tentang perbuatan manusia itu sendiri maupun ilmu-ilmu umum sebagai ilmu pengembangan akal dan kecerdasan manusia. An-Nabhânî hanya melihat aspek mudharatnya terhadap akidah peserta didik, dalam artian ilmu yang hukum asalnya mubah akan menjadi haram ketika mendatangkan mudharat terhadap peserta didik.

Konteks ilmu dalam pemikiran an-Nabhânî di sini memiliki spektrum yang universal, sinergi, dan non-dikotomik. Artinya wilayah ontologis pendidikan Islam harus disinergikan dan dijauhkan dari adanya dikotomi ilmu-ilmu profan dengan ilmu-ilmu agama, ini berarti an-Nabhânî dengan pemikiran-pemikiran dan akidah rasionalitasnya mencoba menghilangkan image dikotomi wahyu dan akal dalam pendidikan Islam. Implementasi kedua ilmu harus sinergi dan universal yang dibangun dengan paradigma akidah Islam sehingga ada kontrol dan proteksi terhadap doktrin atau ajaran yang dapat mendatangkan mudharat bagi peserta didik.

Ilmu filsafat misalnya, oleh an-Nabhânî membolehkan untuk dipelajari meskipun ilmu tersebut berkaitan dengan tsaqafah tertentu, namun ilmu filsafat hanya sekedar untuk diketahui supaya bisa mengkanter dan menyingkap kebatilan-kebatilannya bukan untuk diamalkan. Alasan beliau membatasi ilmu filsafat dipelajari hanya untuk menyingkap kebatilannya bisa dipahami dari dua hal; Pertama, pemikiranpemikirannya yang melarang untuk mengadopsi dari luar islam apabila mengandung nilai budaya yang bertentangan dengan ajaran Islam karena hal tersebut dapat membahayakan pemikiran dan akidah umat Islam. Kedua, pendidikan menurutnya

39 Taqiyuddin an-Nabhânî, Muqaddimah ad-Dustur, 413.

${ }^{40}$ Taqiyuddin an-Nabhânî, Muqaddimah ad-Dustur, 417. 
bukan sekedar proses transfer ilmu kepada peserta didik dalam bentuk penguasaan prinsip-prinsip ilmu sebagai sebuah objek kajian ilmiah sebagaimana umumnya paradigma keilmuan dan metodologi Barat. Akan tetapi peserta didik diarahkan untuk membangun Persepsi dan memiliki integritas kepribadian Islam yang tinggi untuk dapat mengamalkannya dalam kenyataan hidupnya sebagai suatu bentuk kesadaran akan hubungannya kepada Allah antara hamba dan Tuhan.

Namun kembali ke pemikiran umum an-Nabhânî yang membolehkan untuk mempelajari segala jenis ilmu, yang dapat dirumuskan bahwa ilmu filsafat yang dimaksud an-Nabhânî di atas adalah filsafat yang menyimpang dari ajaran Islam, seperti filsafat ketuhanan atau Ilmu yang membahas masalah ketuhanan, akidah dan keimanan, bukan filsafat dalam arti yang general. Karena sangat Naif ketika beliau yang memiliki aqidah rasional menolak filsafat dan mengeneralisasikannya sebagai ilmu yang harus diungkap kebatilannya, sementara dalam Alquran sendiri terdapat ayat-ayat yang menggambarkan premis-premis mantiq ${ }^{41}$ dan cara berpikir filosofis.

Sampai di sini, dapat diketahui klasifikasi ilmu pengetahuan menurut an-Nabhânî berdasarkan spesialisasinya adalah;

1. Ilmu-ilmu terapan (funun) melalui proses observasi, eksperimen, dan inferensial.

2. Ilmu-ilmu tsaqafah melalui proses akhbar, istinbath dan talaqqi.

3. Ilmu-ilmu pengembangan bakat, seperti seni dan keterampilan

Sedangkan klasifikasi berdasarkan objek dan manfaatnya sebagaimana berikut:

1. Ilmu yang mendatangkan manfaat dan tidak merusak aqidah. Yaitu manfaat untuk pribadi, masyarakat, dan umat secara keseluruhan. Ilmu ini wajib untuk dipelajari baik ilmu-ilmu profan maupun ilmu-ilmu tsaqofah.

2. Ilmu yang mendatangkan mudharat terhadap akidah Islam. Ilmu ini dibahasakan al-Ghazali sebagai ilmu yang tercela seperti ilmu sihir, azimat, ramalan nasib.

3. Ilmu yang dipelajari hanya untuk menyingkap kebatilan dan kerusakannya. Seperti ilmu filsafat ketuhanan dan yang sejenisnya.

Adapun pembagian berdasarkan tinjauan aksiologinya menjadi dua bagian yaitu:

1. Ilmu yang bebas nilai dari pengaruh budaya sehingga bersifat terbuka dan universal.

2. Ilmu yang tidak terlepas dari unsur dari kepentingan budaya tertentu yang bertentangan dengan nilai-nilai ajaran Islam.

Kurikulum pelajaran ilmu-ilmu terapan dan profan boleh saja diajarkan kepada peserta didik pada semua tingkatan apabila sesuai dengan keperluan, kemampuan, dan kemauannya, hanya saja ditekankan setelah peserta didik telah mendalami pengetahuan agama dengan sempurna, pada tingkat perguruan tinggi. ${ }^{42}$

Secara konkrit pengklasifikasian an-Nabhânî terhadap fase atau jenjang pendidikan ke dalam tiga tingkatan; Tingkat Dasar (Ibtidaiyah), Tingkat Menengah (Tsanawiyah), dan Tingkat Tinggi ('Aliyah) merupakan penjenjangan secara umum berdasarkan kebutuhan dan daya serta serat peserta didik terhadap materi pelajaran. Sehingga kurikulumnya menyesuaikan dengan jenjang pendidikan. Materi pelajaran

${ }^{41}$ Seperti ayat, لو كان فيهما ءالهة إلا الله لفسدتا sekiranya di bumi dan di langit ini ada Tuhan selain Allah, niscaya keduanya akan hancur), (QS.21:22)

42 Taqiyuddin an-Nabhânî, Muqaddimah al-Dustur, 418. 
pembentukan pribadi Islam merupakan materi wajib dalam kurikulum pendidikan sejak tingkat dasar yang harus kontinyu secara sistematis hingga ke tingkat menengah dan perguruan tinggi, karena tampaknya an-Nabhânî menjadikan akidah Islam sebagai ilmu dasar dan utama anak didik sebelum mempelajari ilmu pengetahuan yang lebih luas.

Sistem pendidikan dijabarkan sesuai jenjang nya mencakup empat aspek utama : 1) pembentukan pribadi Islam, 2) tsaqafah Islam dan tsaqafah umum 3) sains dan 4) skill. sebagaimana dalam tabel di bawah ini:

Tabel. 1. Sistem pendidikan menurut an-Nabhânî:

\begin{tabular}{|c|c|c|c|}
\hline \multirow{2}{*}{$\begin{array}{l}\text { Jenjang Pendidikan } \\
\text { Komponen Materi }\end{array}$} & \multirow[t]{2}{*}{ Ibtidaiyah/Dasar } & \multirow{2}{*}{$\begin{array}{l}\text { Tsanawiyah/ } \\
\text { Menengah }\end{array}$} & \multirow{2}{*}{$\begin{array}{l}\text { Aliyah/ } \\
\text { Tinggi }\end{array}$} \\
\hline & & & \\
\hline Pembentukan Pribadi Islam & Dasar-dasar & Pembentukan & Pematangan \\
\hline Islam & Dasar/Pengenalan & Pemahaman & $\begin{array}{l}\text { Pengembangan } \\
\text { Pelaksanaan }\end{array}$ \\
\hline $\begin{array}{l}\text { Umum/Tidak } \\
\text { bertentangan dengan } \\
\text { Islam }\end{array}$ & Pengenalan & Pemahaman & $\begin{array}{l}\text { Pengembangan } \\
\text { Perbandingan } \\
\text { Pelaksanaan }\end{array}$ \\
\hline $\begin{array}{l}\text { Umum/bertentangan } \\
\text { dengan Islam }\end{array}$ & - & & $\begin{array}{l}\text { Wawasan } \\
\text { Pengetahuan } \\
\text { Kritikan }\end{array}$ \\
\hline Ilmu-ilmu sains/profan & $\begin{array}{l}\text { Sesuai } \\
\text { kemampuan dan } \\
\text { kebutuhan anak }\end{array}$ & $\begin{array}{l}\text { Sesuai } \\
\text { kemampuan } \\
\text { dan kebutuhan }\end{array}$ & $\begin{array}{l}\text { Pengembangan } \\
\text { Pengamatan } \\
\text { Penemuan } \\
\text { Penerapan }\end{array}$ \\
\hline Seni dan Skill/Ketrampilan & $\begin{array}{l}\text { Sesuai } \\
\text { kemampuan dan } \\
\text { kebutuhan anak }\end{array}$ & $\begin{array}{l}\text { Sesuai } \\
\text { kemampuan } \\
\text { dan kebutuhan }\end{array}$ & $\begin{array}{l}\text { Pengembangan } \\
\text { Penemuan } \\
\text { Kreativitas/Karya }\end{array}$ \\
\hline
\end{tabular}

Dari tabel tersebut dirumuskan bahwa untuk membentuk kepribadian Islam masjid dibangun dengan akal dan jiwa yang Islami, karena kemantapan jiwa dan akal mampu melahirkan output dan outcome yang signifikan. Meski demikian, pembentukan akal dan jiwa harus juga ditopang dengan keilmuan lainnya, karena ilmu-ilmu tsaqafah, sains dan skill misalnya, akan sangat membantu pengembangan akal dan jiwanya. Hanya, saja ilmu-ilmu tersebut mesti didasarkan pada Aqidah Islam sehingga anak didik Mampu memiliki pemahaman dan kesadaran yang tinggi untuk melakukan pembedaan dengan tolak ukur nilai-nilai ajaran Islam.

Dari sini dapat dipahami bahwa konsep an-Nabhânî yang menolak sistem pendidikan Islam yang melakukan dikotomi antara ilmu ilmu agama dan ilmu ilmu sains. Baginya, kedua ada keduanya adalah ilmu yang harus diraih oleh umat Islam dalam menata masyarakat yang ideal dan membangun peradaban yang kuat. Hanya saja beliau berbeda dengan ide-ide islamisasi sains yang dikemukakan Ismâîl alFârûqî dan ide integritas ilmu pengetahuan yang dikampanyekan Naquib al-Attâs. Beliau mengusung konsep-konsep pendidikan non-dikotomi yang bersifat sinergis 
(bukan dalam anak integritas dan Islamisasi) antara ilmu-ilmu tsaqafah, ilmu-ilmu sains, dan ilmu-ilmu pengembangan seni dan keterampilan. An-Nabhânî tidak melihat bahwa ilmu-ilmu sains perlu di-Islamisasikan ataupun diintegrasikan menjadi satu, karena ilmu tersebut memiliki objek dan khasnya yang tersendiri. Tetapi ilmu-ilmu tersebut harus dibentuk secara sinergis sebagai suatu penggabungan yang dapat menguatkan secara bersama dengan standar dan tolak ukur ajaran Islam. Empat aspek yaitu kepribadian Islami, ilmu-ilmu tsaqafah, ilmu ilmu sains/profane serta seni dan keterampilan harus dibangun secara sinergis sebagai komponen materi pelajaran yang harus diberikan kepada peserta didik sesuai tuntutan kebutuhannya.

Konsep pendidikan Islam yang ditawarkan di atas dalam tataran implementasinya senantiasa dan harus didukung oleh legitimasi dan otoritas suatu kekuasaan, dalam artian implementasi pendidikan Islam adalah bagian dari tanggungjawab Negara, bahkan menjadi kewajiban bagi Negara. ${ }^{43}$

\section{Kesimpulan}

Konsep pendidikan Taqiyuddin an-Nabhani terbagi menjadi dua bagian yakni 1. Pendidikan Sebagai Interaksi Budaya, Ilmu dan Peradaban, dan 2. Konsep pendidikan Islam an-Nabhânî. Kebudayaan menurut perspektif an-Nabhânî dalam bahasa Arab disebut tsaqafah memiliki perbedaan substantif dengan ilmu. Ilmu adalah pengetahuan (ma'rifah) yang diperoleh melalui jalan mulahazhah (observasi), tajribah (eksperimen) dan istintaj (inferensial). Berbicara tentang konsep pendidikan berarti membicarakan eksistensi atau hakikat manusia dalam mengelola kehidupannya, karena manusia adalah subjek sekaligus objek pendidikan. Oleh karena itu, untuk mengawali uraian konsep pendidikan an-Nabhânî, akan diuraikan terlebih dahulu hakikat penciptaan manusia. Manusia menurut an-Nabhânî memiliki hubungan yang tidak terpisahkan dengan alam semesta (al-Kaun), dan kehidupan (al-Hayat). Ketiganya merupakan unsur materi, bukan ruh dan bukan juga campuran materi dan ruh. Manusia sebagai unsur materi artinya sesuatu yang dapat dijangkau dengan indra, apakah materi itu diartikan sebagai sesuatu yang menempati ruang dan memiliki massa, atau diartikan sebagai tenaga yang dapat menggerakkan, baik materi itu abstrak maupun kongkrit.

\section{DAFTAR PUSTAKA}

Arif, Nashr Muhammad. Al-Hadlarah, ats-Tsaqafah, al-Madaniyah; Dirasat li Sirat alMushtalah wa Dalalah al-Mafhum. Virginia: al-Ma'had al-Alam al-Fikri al-Islami, 1994.

Arifin. Filsafat Pendidikan Islam. Jakarta: Bumi Aksara, 1996.

Freire, Paulo. Sekolah Kapitalisme yang Licik. Yogyakarta: LKiS, 2001.

Al-Hijazi, Hasan ibn Ali. Manhaj Tarbiyah Ibnu Qayyim. Jakarta: Pustaka Kautsar, 2001.

Illich, Ival. Bebaskan Masyarakat dari Belenggu Sekolah. Jakarta: Yayasan Obor Indonesia, 2000.

Al-Jumbulati, Ali. Perbandingan Pendidikan Islam. Jakarta: Rineka Cipta, 1994.

43 Taqiyuddin an-Nabhânî, Muqaddimah al-Dustur, 420. Sebab itu, untuk melihat lebih dekat bagaimana peran dan tanggungjawab Negara terhadap pendidikan Islam, akan di bahas secara khusus hubungan politik dengan pendidikan Islam pada bab berikutnya dan merupakan kajian utama dalam tesis ini. 
Mahmud, Abdul Halim. Pendidikan Ruhani. Jakarta; Gema Insani Press, 2000.

Manzur, Abu al-Fadhl Jamaluddin Muhammad ibn Mukrim Ibn. Lisan al-Arab, Jilid 4.

Beirut: Dar Shadir, 1990.

Muhaimin, Paradigma Pendidikan Islam. Bandung: Remaja Rosdakarya, 2002.

An-Nabhânî, Taqiyuddin. Nizham al-Islam. t.tp: Hizbut Tahrir, 2001.

An-Nabhânî, Taqiyuddin. as-Syakhsiyah al-Islamiah. t.tp: t.p, t.t.

An-Nabhânî, Taqiyuddin. Pokok-pokok Pikiran Hizbut Tahrir, terj. Abu Afif. Indonesia: Thariqul Izzah, 1993.

An-Nabhânî, Taqiyuddin. Muqaddimah ad-Dustur. t.tp: t.p., 1963.

Sulaeman, Fathiah Hasan. Mazhab fi at-Tarbiyah: Bahtsun fi al-Madzhab at-Tarbawi inda al-Ghazali. Kairo: Maktabah Nahdhah, 1964.

Taqiyuddin an-Nabhânî. As-Syakhsiyah a;-Islamiyah. Libanon: Dar al-Ummah, 1994.

Al-Thariq, Ahmad 'Athiat. Dirasat Fikriyah fi Kaefiyat al-Amal li taghyir Waqi' al-Ummah wa Inhadhiha. Libanon: Dar al-Bayarik, 1996.

Wamy. Gerakan keagamaan dan Pemikiran, Akar Ideologis dan Penyebarannya. Jakarta: al-Ishlahy Press, 1995.

Zallum, Abdul Qadir. Mengenal Sebuah Gerakan Islam di Timur Tengah, terj. Abu Afif dan Nur Kholish. Surabaya: CV El-Fath, tt. 